\title{
BACTERIAL PROFILE AND THEIR ANTIBIOGRAM IN CASES OF CHRONIC SUPPURATIVE OTITIS MEDIA
}

\author{
Samiullah', Mohd Rashid ${ }^{2}$ \\ ${ }^{1}$ Associate Professor, Department of ENT, Era's Lucknow Medical College and Hospital, Sarfarazganj, Lucknow, Uttar Pradesh. \\ ${ }^{2}$ Associate Professor, Department of Microbiology, F. H. Medical College, Near Etmadpur, Firozabad, Uttar Pradesh.
}

ABSTRACT: BACKGROUND: In Chronic Suppurative Otitis Media (CSOM), the spread of micro-organisms to adjacent structures can result in a broad range of intracranial and extracranial complications.

OBJECTIVES: The aim of our study was to determine the microbial profile and their anti-biogram pattern and to prepare a protocol for empircal antibiotic therapy based on the local pattern of microbial isolates.

SETTINGS AND DESIGN: This prospective study was conducted in the E.N.T. outpatient Department of Era's Lucknow Medical College.

MATERIALS AND METHODS: Middle ear discharges were collected and cultured from 80 CSOM diagnosed patients attending the ENT clinic. The organisms isolated were identified by standard microbiological methods and antibiogram pattern was determined.

RESULTS: The most commonly affected sex is female with 55\% cases in comparison to males where only $45 \%$ cases were found to be positive for CSOM. CSOM mostly affected the individuals in the age group of 21-30 years. Most widespread organism isolated was Pseudomonas spp. [25 (31.25\%)] followed by Staphylococcus aureus [16 (20\%)] and Coagulase negative staphylococcus [9 (11.25\%)]. Gram negative bacteria showed $>80 \%$ sensitivity to Ceftazidime, Ciprofloxacin, Lomefloxacin, Gentamicin and Netilline wehereas gram positive bacteria shows $>90 \%$ sensitivity to Cephalexin, Linezolid and Gentamdicin.

CONCLUSION: The knowledge of the local pattern of infection is essential for starting empirical treatment and reducing the potential risks of complications. Periodic monitoring of the microbiological profile along with their sensitivity pattern is essential for formulating an effective antibiotic policy for CSOM.

KEYWORDS: Antibiogram, Antibiotic Resistance, Bacterial Isolates, Chronic Supparative Otitis Media, Culture and Sensitivity.

HOW TO CITE THIS ARTICLE: Samiullah, Mohd Rashid. "Bacterial Profile and their Antibiogram in Cases of Chronic Suppurative Otitis Media". Journal of Evolution of Medical and Dental Sciences 2015; Vol. 4, Issue 90, November 09; Page: 15530-15533,

DOI: $10.14260 /$ jemds/2015/2224.

INTRODUCTION: Ear is responsible for hearing and maintaining balance and it's the first sensory organ to develop. It is divided into the inner, middle and outer ear with the middle and outer regions being most susceptible to injury and infections.[1] Ear infections are of different types with otitis media being the most common.[2] Chronic suppurative otitis media (CSOM) is defined as chronic inflammation of middle ear and mastoid cavity that may present with recurrent ear discharges through a tympanic membrane perforation. ${ }^{[3]}$

Due to the perforated tympanic membrane, microorganisms can gain entry into the middle ear via the external ear canal. Infection of the middle ear mucosa subsequently results in ear discharge. Incidence of this disease is higher in developing countries especially among low socio-economic society because of malnutrition, overcrowding, poor hygiene condition, inadequate health care and recurrent upper respiratory tract infection.[4]

The urban to rural ratio of the disease is $1: 2$ and the poorer rural communities have its highest prevalence.[5]

Also, it is one of the most common causes of deafness and can also cause permanent perforation of the tympanic membrane.[6]

Financial or Other, Competing Interest: None.

Submission 15-10-2015, Peer Review 16-10-2015,

Acceptance 28-10-2015, Published 07-11-2015.

Corresponding Author:

Dr. Mohd. Rashid,

Associate Professor

Department of Microbiology, F. H. Medical College,

Near Etmadpur, Railway Over Bridge NH- Tundla Dist,

Firozabad-283201, Uttar Pradesh.

E-mail: rashidmohddr@yahoo.co.in

DOI: $10.14260 / j e m d s / 2015 / 2224$.
The disease usually occurs after upper respiratory viral infections followed by invasion of pyogenic organisms. ${ }^{[7]}$ Many studies have showed that the common organisms isolated from cases of CSOM are found to be Pseudomonas spp., Staphylococcus aureus, Klebsiella pneumoniae and Proteus spp. CSOM can cause severe adverse effects like intra and extracranial complications which can be life threatening. The incidence of CSOM is increasing in the developing countries because of the poor hygienic practices and lack of health education.

The complications of CSOM have been reduced to a greater extent because of the invention of antibiotics. But irrational use of antibiotics has lead to the emergence of resistant organisms to the commonly used drugs.

Hence this study is carried out to know the bacterial etiology of CSOM and their antibiotic susceptibility pattern. This knowledge is very important for the clinicians for appropriate management of the cases and to prevent or minimise the occurrence of complications. Treatment of the cases after studying the antimicrobial susceptibility pattern will help in preventing the emergence of resistant strains in the community.

MATERIALS AND METHODS: 80 clinically diagnosed cases of CSOM from E.N.T. outpatient department of Era's Lucknow Medical College were taken for the study. The ear discharge from the middle ear was collected by sterile swabs under aseptic conditions and sent to the department of Microbiology for bacterial culture.

Samples were collected from those patients who had not taken any treatment either locally or systemic for the last 7 days. The sample was examined microscopically for the presence of pus cells, and bacteria. For culture sample was plated on 5\% sheep blood agar and MacConkey agar. 
The organisms were identified by morphology, cultural characteristics and pigment production followed by conventional biochemical tests. The antibiotic susceptibility testing of the bacterial isolates was done by Kirby-Baeur's disc diffusion method on Mueller Hinton agar according to CLSI guidelines.[8]

RESULT: CSOM has received more attention because of its higher incidence and also due to increasing bacterial resistance to both topical and systemic antibiotics. The study was carried out in a total of 80 patients comprising 36 males and 44 females (Figure 1, Table 1).

In our study group maximum numbers of cases were from the female group 44 cases (55\%) and males were $36(45 \%)$.

In this study, maximum number of cases i.e. $22(27.5 \%)$, were from the age group 21 to 30 years (Table 2, Figure 2). Out of total 80 specimens, 11 showed no growth of organism while 69 specimens showed growth of one or two organisms. Out of 69 specimens, 58 showed single isolate and 11 showed two isolates.

The occurrence of gram negative organisms (GNB) was higher than gram positive (GPB) with GNB 51/80 (63.75\%), GPB 29/80 (36.25\%). In our study, out of 80 bacterial isolates, Pseudomonas spp., Proteus spp., Citrobacter spp., Klebsiella spp., Acinetobacter spp., Enterobacter spp. and E. coli were the most common GNB isolated whereas GPB Staphylococcus aureus, CONS and Streptococcus spp. were the most common (Table 3).

GNB showed $>80 \%$ sensitivity to Ceftazidime, Ciprofloxacin, Lomefloxacin, Gentamicin and Netilline. $>75 \%$ sensitivity to Pefloxacin, Ofloxacin, Cefaperazone and Amikacin. They are resistance to Amoxyclav, Cefotaxime and Cefuroxime (Table 4 ).

GPB shows $>90 \%$ sensitivity to Cephalexin, Linezolid and Gentamicin. $>80 \%$ sensitivity Cloxacillin, Cefotaxime, Lincomycin, Co-trimoxazole, Tetracycline and Amoxyclav (Table 5).

DISCUSSION: An ear infection (Otitis Media) refers to an infection of the middle part of the ear. It can occur at any age but it is common in babies and young children, especially those aged between 6 to 18 months. Most children will have an ear infection before the age of 5 years. ${ }^{[1]}$ CSOM is the chronic inflammation of middle ear, which affects the tympanic membrane, middle ear mucosa and other middle ear structures.[9]

In our study, maximum numbers of cases i.e. 44 cases $(55 \%)$ were female and $36(45 \%)$ were males. Whereas maximum number of infection i.e. 22 cases $(27.5 \%)$ were from the age group 21 to 30 years. The ear infection rate in this study is similar to that of Raakhee T et al. 2014, which shows majority of the patients who had ear discharge was between 16-25 years.

This was followed by the age group between $6-15$ years.[10] Studies carried out by Raakhee T et al. 2014 showed that females were most commonly affected than males which are consistent with our results.[10]

Whereas our result contradicts the result obtained by Humera Rashid et al.

where $54 \%$ male and $46 \%$ females and R Shyamala et al. where $57 \%$ males and $43 \%$ females were mostly affected by CSOM.[11.12]
The bacteriologic study of otitis media revealed the isolation of a variety of organisms. Pseudomonas spp. is the most prominent organism being isolated in $25(31.25 \%)$ of the cases followed Staphylococcus aureus in 16 (20\%) cases, CONS in $9(11.25 \%)$ cases, Proteus spp. in 7 cases $(8.75 \%)$ and Klebsiella spp. in 5 cases (6.25\%). Iqbal et al. examined 200 ear swabs the bacterial isolates were P. aeruginosa $41.5 \%$ Staphylococcus spp. 19\%, Proteus mirabilis 18\%, and Klebsiella pneumonia $10.5 \%$, E. coli $4 \%$ and Beta-hemolytic Streptococcus $5 \%{ }^{[13]}$ In another study, Gul et al. found that the frequency of P. aeruginosa in CSOM was $52.2 \%$, S. aureus $15 \%$, Proteus spp. $6.5 \%$ and Klebsiella spp. $2.6 \% .^{[14]}$

These results correspond to the frequency of bacterial isolates obtained in our study as well. Pseudomonas spp. in our study showed high sensitivity to Ofloxacin (95.44\%), Pefloxacin (94.8\%), Gentamicin (94.8\%), Ciprofloxacin (93.2\%), Cefaperazone (90.3\%) and Amikacin (89.74\%). Antibiogram in this study showed $>90 \%$ sensitivity to Ceftazidime, Ciprofloxacin, Lomefloxacin, Gentamicin and Netilline for GNB whereas $>90 \%$ sensitivity to Linezolid, Gentamicin and Tetracycline for GPB, this corresponds to the results obtained by Rakhee and Srinivasa however different workers showed different sensitivity patterns.[10,12]

CONCLUSION: A large variation can be seen in the organisms infecting and their susceptibility pattern in ear infection. In our study Pseudomonas, Proteus, Klebsiella, Acinetobacter, Staphylococcus aureus and CONS were the most important organisms associated with ear infection. For GNB, Ceftazidime, Ciprofloxacin, Lomefloxacin, Gentamicin and Netilline and for GPB, Cephalexin, Linezolid, Gentamicin, Amoxyclav and Tetracycline appear to be the first line antibiotic to treat CSOM. The patients should also be advised to complete the drug course without stopping in between. This will not only help in minimizing the complications, but also help in preventing the emergence of resistant strains. Microbial predominance and their antibiotic sensitivity pattern change over time due to the climate, antibiotic usage and geographic factors. So periodical monitoring of microbiological profile of CSOM cases is essential for making effective empirical protocol for the cases in the particular locality.

\section{REFERENCES:}

1. Richard EB, Roberts MK. Otitis media and its complications in Nelson's Texbook of peadiatrics. 1996; 1814-1824.

2. Weiner R, Collison PJ. Midddle ear pathogens in otitis prone children. South Dakota J Med 2003; 56: 103-107.

3. Acuin J Geneva: World Health Organisation; 2004. Global burden of disease due to chronic suppurative otitis media: Disease, deafness, deaths and DALYs Chronic Suppurative Otitis Media-Burden of Illness and Management Options; pp. 9-23.

(Accessed August 29, 2012).

4. Kumar H, Seth S. Bacterial and fungal study of 100 cases of chronic suppurative otitis media. J Clin Diagn Res 2011; 5: 1224-1227.

5. Ologe FE, Nwawolo CC. Chronic suppurative otitis media in school pupils in Nigeria.

East Afr Med J 2003; 80: 130-134.

6. Shenoi PM. Management of chronic suppurative otitis media. Scott Brown's textbook of Otorhinolaryngology. 5th Edition. 1988; 3: 215. 
7. Fliss DM, Shoham I, Leiberman A, Dagan R. Chronic suppurative otitis media without cholesteatoma in children in southern Israel: incidence and risk factors. Paediatric infection disease journal 1991; 10: 895-899.

8. National Committee for Clinical Laboratory standards. Performance Standards for Antimicrobial Susceptibility Testing. Wayne, PAUSA: NCCLS; 200: M100-S1.

9. Iqbal JB, Khan W, Raza SN, Naqvi NU, Rahat ZM, Azeem QE. Frequency of chronic suppurative otitis media in the junior ranks of Pak army. Pak Armed Forces Med J 2009; 59: 367-70.

10. Raakhee T, Sreenivasa Rao Unguturu. Bacteriological study of discharging ear in patients attending a tertiary care hospital. Int J Res Med Sci 2014; 2(2): 602-606.
11. Rashid H, Zeb M, et al. Frequency and antimicrobial susceptibility pattern of pseudomonas aeruginosa in ear swabs.

World Applied Sciences Journal 2014; 30 (7): 812-817.

12. Shyamala R, Sreenivasulu PR. The study of bacteriological agents of chronic suppurative Otitis media-Aerobic culture and evaluation.

J Microbiol Biotech Res 2012; 2 (1): 152-162.

13. Iqbal SM, Udaipurwala IH, Hasan A, Shafiq M, Mughal S. Chronic suppurative otitis media: disease pattern and drug sensitivity. Journal of Surgery Pakistan 2006; 11(1): 17-19.

14. Gul AA, Ali L, Rahim E, Ahmed S. Chronic suppurating otitis media; frequency of pseudomonas aeruginosa in patients and sensitivity to various antibiotics. Professional Medical Journal 2007; 14(3): 411-415.

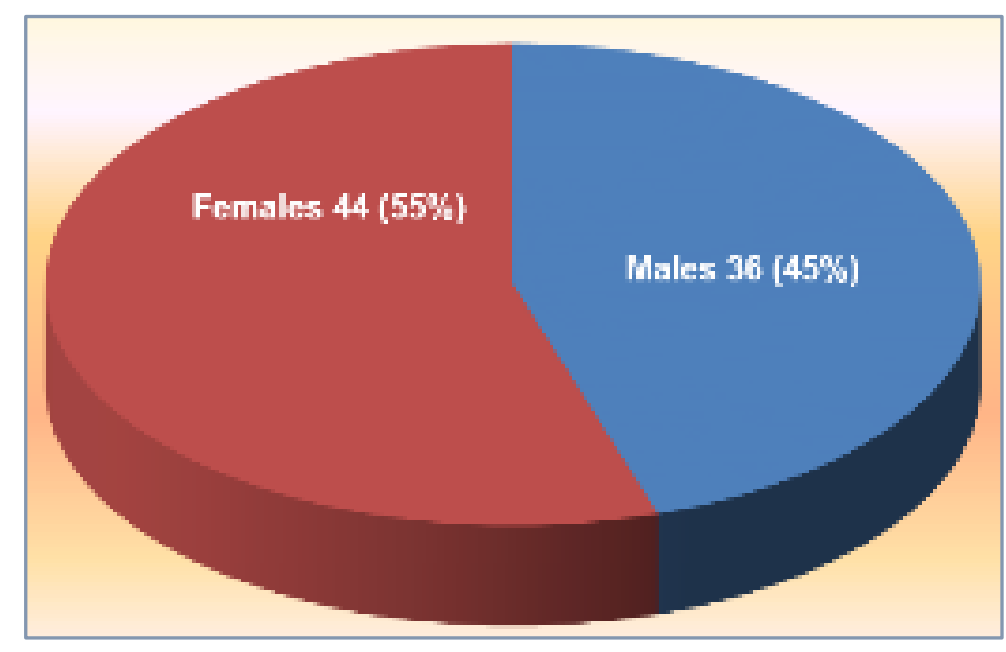

Figure. 1: Sex wise distribution of clinically diagnosed cases of CSOM

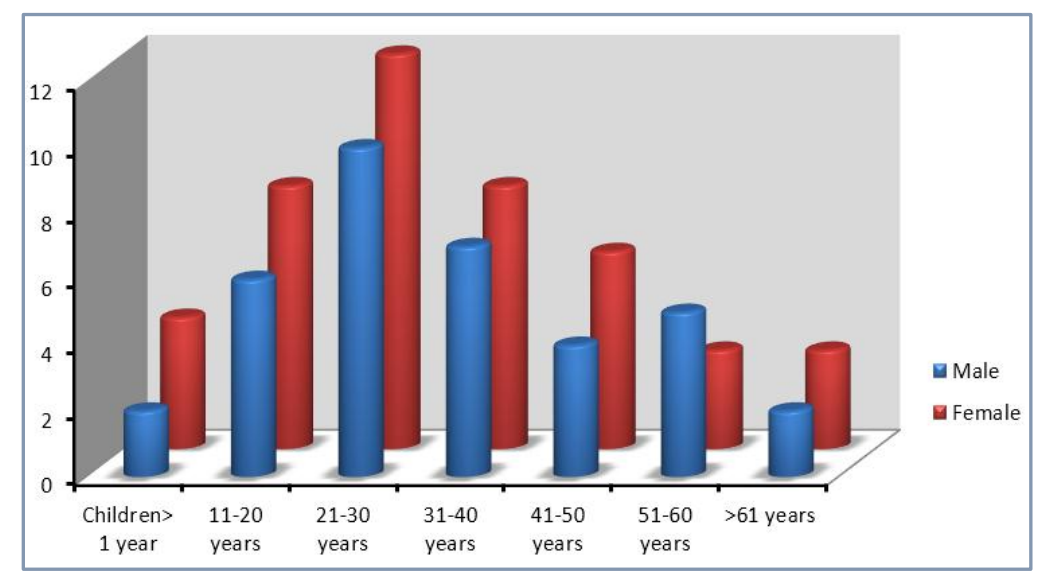

Figure. 2: Age wise distribution of CSOM affected males and females

\begin{tabular}{|c|c|c|}
\hline Sex & Number & \% \\
\hline Male & 36 & $45 \%$ \\
\hline Female & 44 & $55 \%$ \\
\hline \multicolumn{3}{|c|}{ Table 1: Sex distribution of cases } \\
\hline
\end{tabular}

\begin{tabular}{|c|c|c|c|c|}
\hline Age Group & Male & Female & $\begin{array}{c}\text { Total } \\
(\mathbf{n = 8 0 )}\end{array}$ & \% \\
\hline Children <1 Year & 2 & 4 & 6 & 7.5 \\
\hline 11 Years to 20 Years & 6 & 8 & 14 & 17.5 \\
\hline 21 Years to 30 Years & 10 & 12 & 22 & 27.5 \\
\hline 31 Years to 40 Years & 7 & 8 & 15 & 18.75 \\
\hline 41 Years to 50 Years & 4 & 6 & 10 & 12.5 \\
\hline 51 Years to 60 Years & 5 & 3 & 8 & 10 \\
\hline >61 Years & 2 & 3 & 5 & 6.25 \\
\hline Table 2: Age wise distribution of Cases \\
\hline \\
n = no of isolates,
\end{tabular}




\begin{tabular}{|c|c|c|c|c|}
\hline Sl. No. & & Organisms & Isolates $(n=80)$ & $\%$ \\
\hline \multirow{7}{*}{1} & \multirow{7}{*}{$\begin{array}{c}\text { Gram Negative Bacteria } \\
\qquad(n=51) 63.75 \%\end{array}$} & Pseudomonas spp. & 25 & 31.25 \\
\hline & & E.coli & 2 & 2.5 \\
\hline & & Klebsiella spp. & 5 & 6.25 \\
\hline & & Proteus spp. & 7 & 8.75 \\
\hline & & Enterobacter spp. & 3 & 3.75 \\
\hline & & Citrobacter spp. & 5 & 6.25 \\
\hline & & Acinetobacter spp. & 4 & 5.00 \\
\hline \multirow{3}{*}{2} & \multirow{3}{*}{$\begin{array}{c}\text { Gram Positive Bacteria } \\
\text { (n=29) } 36.25 \%\end{array}$} & Staphylococcus aureus & 16 & 20.00 \\
\hline & & Streptococcus spp. & 4 & 5.00 \\
\hline & & Coagulase negative staphylococcus & 9 & 11.25 \\
\hline \multicolumn{5}{|c|}{ Table 3: Aerobic bacteria isolated from ear infection } \\
\hline
\end{tabular}

$\mathrm{n}=$ no of isolates,

\begin{tabular}{|c|c|c|c|c|c|c|c|}
\hline $\begin{array}{l}\text { Sl. } \\
\text { No. }\end{array}$ & Antibiotics & $\begin{array}{c}\text { Antibiotics } \\
\text { Symbol }\end{array}$ & $\begin{array}{c}\text { Pseudomon } \\
\text { as } \\
\text { spp. }(n=25) \\
\%\end{array}$ & $\begin{array}{c}\text { Proteus } \\
\text { spp. }(n=7) \\
\%\end{array}$ & $\begin{array}{c}\text { Klebsiell } \\
\text { a spp. } \\
(n=5) \\
\%\end{array}$ & $\begin{array}{c}\text { Acinetoba } \\
\text { cter spp. } \\
(n=4) \\
\%\end{array}$ & $\begin{array}{c}\text { Enterobacter } \\
\text { spp. }(n=3) \\
\%\end{array}$ \\
\hline 1 & Pefloxacin & $\mathrm{PF}$ & 94.8 & 75 & 100 & 77 & 100 \\
\hline 2 & Ofloxacin & $\mathrm{OF}$ & 95.44 & 100 & 100 & 75 & 100 \\
\hline 3 & Ciprofloxacin & $\mathrm{RC}$ & 93.2 & 100 & 100 & 100 & 100 \\
\hline 4 & Lomefloxacin & LO & 88.1 & 100 & 100 & 100 & 66.7 \\
\hline 5 & Cefaperazone & $\mathrm{CS}$ & 90.3 & 87.5 & 100 & 100 & 100 \\
\hline 6 & Amikacin & $\mathrm{AK}$ & 89.74 & 87.5 & 100 & 100 & 100 \\
\hline 7 & Gentamicin & G & 94.8 & 100 & 100 & 100 & 66.6 \\
\hline 8 & Netilline & NT & 80 & 100 & 100 & 100 & 100 \\
\hline 9 & Cefuroxime & $\mathrm{CU}$ & $\mathrm{R}$ & 87.5 & 58 & $\mathrm{R}$ & 66.67 \\
\hline 10 & Cefotaxime & $\mathrm{CE}$ & $\mathrm{R}$ & 87.5 & 76 & 65 & 66.6 \\
\hline 11 & Ceftazidime & CA & 100 & 100 & 100 & 82 & 100 \\
\hline 12 & Amoxyclav & AMC & $\mathrm{R}$ & $\mathrm{R}$ & $\mathrm{R}$ & $\mathrm{R}$ & $\mathrm{R}$ \\
\hline \multicolumn{8}{|c|}{ Table 4: Antibiogram of Gram-negative isolates } \\
\hline
\end{tabular}

$\mathrm{n}=$ no of isolates,

\begin{tabular}{|c|c|c|c|c|}
\hline $\begin{array}{l}\text { Sl. } \\
\text { No. }\end{array}$ & Antibiotics & $\begin{array}{c}\text { Antibiotics } \\
\text { Symbol }\end{array}$ & $\begin{array}{c}\text { Staphylococcus } \\
\text { aureus }(n=16) \%\end{array}$ & $\begin{array}{c}\text { CONS } \\
(n=9) \%\end{array}$ \\
\hline 1 & Cloxacillin & $\mathrm{CX}$ & 82.2 & 88.8 \\
\hline 2 & Ampicillin+Sulbactam & AS & 76 & 73.4 \\
\hline 3 & Cefotaxime & CE & 76 & 82.7 \\
\hline 4 & Roxythromycin & AT & 76 & 58.1 \\
\hline 5 & Cefotaxime & $\mathrm{CF}$ & 82.2 & 87.7 \\
\hline 6 & Ciprofloxacin & $\mathrm{RC}$ & 54.2 & 87.7 \\
\hline 7 & Tetracycline & TE & 85.5 & 100 \\
\hline 8 & Linezolid & $\mathrm{LZ}$ & 94.7 & 100 \\
\hline 9 & Cephalexin & PR & 92.7 & 100 \\
\hline 10 & Co-trimoxazole & BA & 86.5 & 82.7 \\
\hline 11 & Gentamicin & $\mathrm{G}$ & 91.7 & 100 \\
\hline 12 & Lincomycin & LM & 91.7 & 82.7 \\
\hline 13 & Amoxyclav & AMC & 85.2 & 100 \\
\hline \multicolumn{5}{|c|}{ Table 5: Antibiogram of gram-positive isolates } \\
\hline
\end{tabular}

$\mathrm{n}=$ no of isolates, 